UDC 547.2/4;547.917/.918;544.4

\title{
CATALYTIC OXIDATION OF OXYGEN CONTAINING ALIPHATIC HYDROCARBONS IN THE PRESENCE OF METALPOLYMER COMPLEXES
}

\author{
R.H. Suleymanova, N.A. Zeynalov, O.T. Badalova, L.N. Qulubayova, \\ A.R. Guliyeva, U.A. Mammadova \\ M.Nagiyev Institute of Catalysis and Inorganic Chemistry \\ 113, H. Javid ave., AZ 1143, Baku, Azerbaijan, e-mail: suleyman.rena@gmail.com
}

Received 02.04.2021

Accepted 20.07.2021

\begin{abstract}
The reactions of liquid-phase oxidation of aliphatic oxygen containing hydrocarbons, in particular, nonanol-4 and nonanon-4 in the presence of polyethylene-polyamine complexes (PEPA) with sorbated ions of metals with changeable valency $\left(\mathrm{Co}^{2+}, \mathrm{Cu}^{2+}, \mathrm{Ni}^{2+}\right)$ were studied. It revealed that the oxidation of nonanole-4 and nonanone-4 in the presence of $\mathrm{Cu}^{2+}$ and $\mathrm{Ni}^{2+}$ ions in the analyzed system is less active while in the presence of $\mathrm{Co}^{2+}$ ions decarboxylation of acids it is practically absent and it leads mainly to formation of carbonic acids. It has been established that the character of oxidation reaction mostly depends on the properties of metals fixed on polymer matrix.
\end{abstract}

Keywords: liquid-phase, oxidation, metal-polymer complex, metal, nonanol-4, nonanon-4, carbonic acids.

DOI: 10.32737/2221-8688-2021-2-94-100

\section{Introduction}

Aliphatic carbonic acids, as well as their salts and ethers are widely used in pharmaceutical, vitamin, cosmetic, food and automobile industries [1-4].

It is well-known that chemical methods of obtaining carbonic acids by means of oxidation of aliphatic alcohols are noted for some deficiencies which are due to the use of rather expensive and toxic chemical oxidants, such as potassium permanganate, chrome complexes and etc [5-7].

Chemically tied active forms of oxygen: 'O-O', ${ }^{\circ} \mathrm{OH}, \mathrm{HO}_{2}{ }_{2}$ that are ecologically pure oxidizing reagents - can be the alternative to these oxidants.

In the previous studies we examined regularities of liquid-phase oxidation of aliphatic hydrocarbons in the presence of metalpolymer complexes. The results showed that in this observed system the reaction runs selectively, with predominant formation of one or two components. Besides, the direction of the process and the rate of products accumulation mainly depend on the quantity and properties of the initiating ion of metal [8-9].

Proceeding from the analysis [10-12] of the regularities of liquid-phase oxidation of saturated hydrocarbons, it revealed that the primary products of the starting stage of oxidation are hydroperoxides, and their decomposition mostly leads to the formation of carbonyl complexes and alcohols. However, it should be emphasized that the latter ones, being in reaction zone under the influence of oxygen, are subjected to further oxidation to form carbonic acids, complicated ethers, carbon dioxide and the products of condensation.

Observation of the system of liquid-phase oxidation of individual, carbonyl complexes and alcohols in the presence of metalpolymer complexes will permit us to identify the regularities of the running processes. For this purpose, the aliphatic alcohol nonalol-4 and the aliphatic ketone nonanon-4 were chosen as a model reaction and an object of investigation. The choice of these compounds is due to the mechanism of attack of aliphatic hydrocarbons by oxygen atoms and the composition of the resulting products. According to references [1314], in the system of liquid-phase oxidation, the most subjected to oxygen atoms attack are methylene groups of hydrocarbon. Therefore, 
the formation of secondary oxygen-containing products is the most favorable.

\section{Experimental part}

The oxidation of nonanol-4 and nonanol-4 was carried out in a bubble type glass reactor with the participation of oxygen torrent, at a temperature of $120^{\circ} \mathrm{C}$ and the atmosphere pressure, in the presence of polyethylenepolyamine (PEPA) disposed to the sorption of ions $\mathrm{Co}^{2+}, \mathrm{Cu}^{2+}$ and $\mathrm{Ni}^{2+}$. In the course of the experiment the selected tests were analyzed for containing hydroperoxides, carbonic acids, and in the exit gases we identified the quantity of carbon dioxide. The obtained hydroperoxides were determined iodometrically, and the acids through the use of reverse titration.

\section{Discussion of results}

The kinetic curves of accumulation of the products of oxidation of nonanol-4 in the presence of $\mathrm{Co}^{2+}$ ions are presented in Fig.1.

As seen from Fig. 1, an oxidation of alcohol leads to the formation of hydroperoxides, carbonyl compounds and carbonic acids. It is obvious that the obtained hydroperoxides and carbonyl compounds are intensively oxidized into carbonic acids. For this reason, the accumulation of the latter grows rather fast, at a small accumulation of the first two products. Under similar conditions reactions were carried out in the presence of $\mathrm{Cu}^{2+}, \mathrm{Ni}^{2+}$ ions. It revealed that the activity of $\mathrm{Cu}^{2+}$ and $\mathrm{Ni}^{2+}$ ions is insignificant.

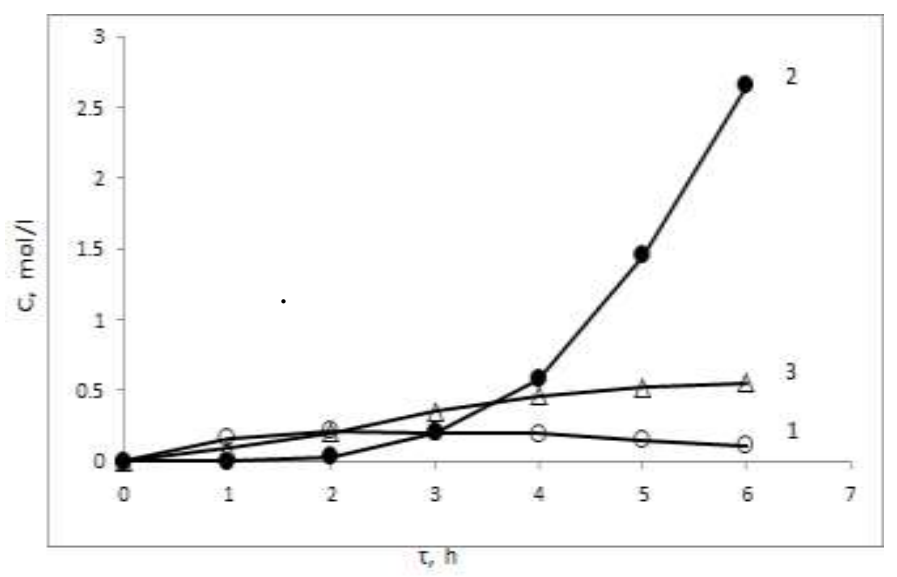

Fig. 1. Kinetic curves of the accumulation of nonanol- 4 oxidation products. T- $-120^{\circ} \mathrm{C}$, catalyst (PEPA) $\mathrm{Co}^{2+}$. 1 - hydroperoxides, 2 - carbonic acids, 3 - carbonyl complexes

The kinetic curves of the accumulation of products of reaction following oxidation of the nonanon-4 in the presence of $\mathrm{Co}^{2+}, \mathrm{Cu}^{2+}, \mathrm{Ni}^{2+}$ ions are shown in Fig. 2,3,4. As is seen from the figures above, the nonanon- 4 oxidation leads mainly to the formation of carbonic acids. The ion $\mathrm{Co}^{2+}$ is distinguished by high initiating property. The activity of ions $\mathrm{Cu}^{2+}$ and $\mathrm{Ni}^{2+}$ is rather small, so the reaction runs rather weak. In Fig.5, there are kinetic curves of thermal oxidation of nonanon-4. With the absence of catalyst in the selected conditions, the rate of reaction is quite insignificant. 


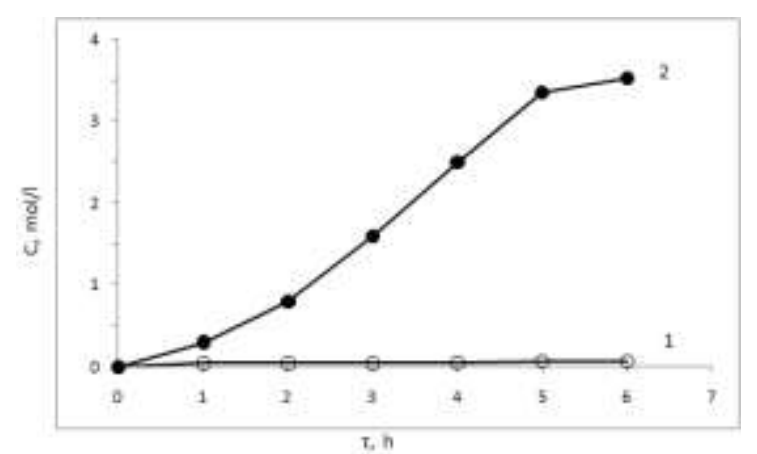

Fig. 2. Kinetic curves of the accumulation of nonanon- 4 oxidation products. $\mathrm{T}-120^{\circ} \mathrm{C}$, catalyst (PEPA) $\mathrm{Co}^{2+} .1$ - hydroperoxides, 2 - carbonic acids.

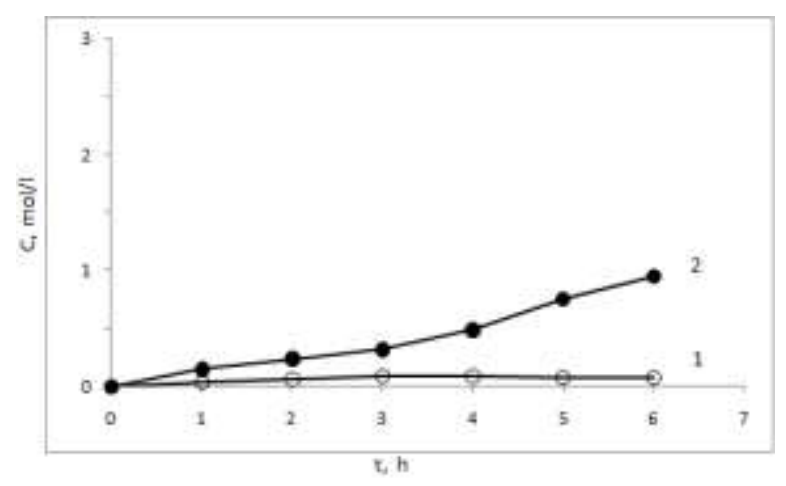

Fig. 4. Kinetic curves of the accumulation of nonanon- 4 oxidation products. T- $120^{\circ} \mathrm{C}$, catalyst (PEPA) $\mathrm{Ni}^{2+}$. 1- hydroperoxides, 2 - carbonic acids.

As shown above, the oxidation of aliphatic alcohol and ketone leads to the formation of mainly carbonic acids, the accumulation of which occurs most intensively in the presence of $\mathrm{Co}^{2+}$ ions in comparison with $\mathrm{Cu}^{2+}$ and $\mathrm{Ni}^{2+}$ ions, which indicates a higher activity of cobalt ions.

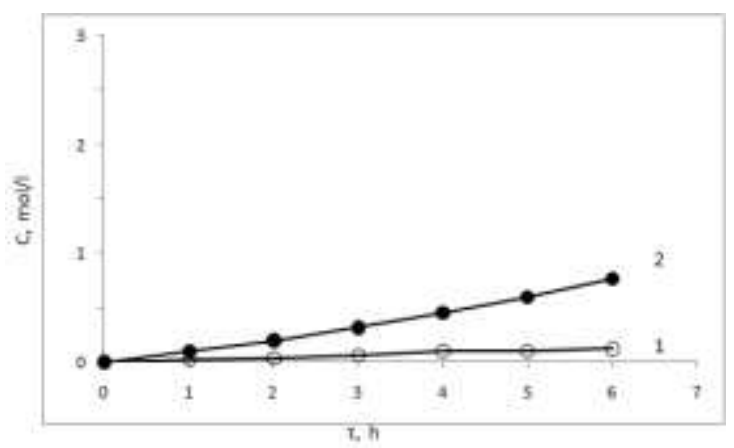

Fig. 3. Kinetic curves of the accumulation of nonanon- 4 oxidation products. $\mathrm{T}-120^{\circ} \mathrm{C}$, catalyst (PEPA) $\mathrm{Cu}^{2+}$. 1- hydroperoxides 2 - carbonic acids.

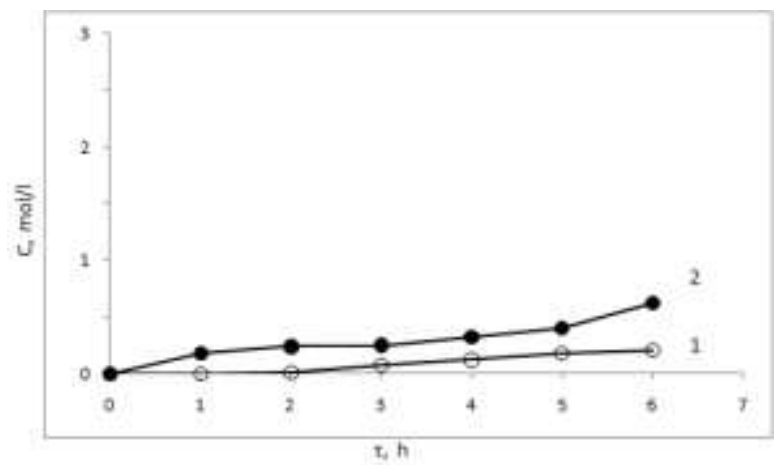

Fig. 5. Kinetic curves of the accumulation of nonanon-4 thermal oxidation products. 1- hydroperoxides, 2 - carbonic acids

Oxidation of alcohol in the presence of PEPA with sorbed cobalt ions can be represented as follows: when it enters into a reaction with nonanol-4, PEPA combined with sorbed cobalt ions o forme a complex with the atoms of oxygen.

$$
\begin{aligned}
& {[\mathrm{PEPA}] \mathrm{Co}^{2+}+\mathrm{O}_{2} \longrightarrow\left[\mathrm{PEPA} \mathrm{Co}{ }^{2+} \cdot \mathrm{O}_{2}\right]} \\
& \mathrm{CH}_{3}-\mathrm{CH}_{2}-\mathrm{CH}_{2}-\mathrm{CHOH}-\mathrm{CH}_{2}-\mathrm{CH}_{2}-\mathrm{CH}_{2}-\mathrm{CH}_{2}-\mathrm{CH}_{3}+\mathrm{O}_{2} \longrightarrow \\
& \mathrm{CH}_{3}-\mathrm{CH}_{2}-\mathrm{CH}_{2}-\mathrm{CHOH}-\mathrm{CH}-\mathrm{CH}_{2}-\mathrm{CH}_{2}-\mathrm{CH}_{2}-\mathrm{CH}_{3} \\
& \left.\right|_{\mathrm{OOH}} \\
& \mathrm{CH}_{3}-\mathrm{CH}_{2}-\mathrm{CH}_{2}-\mathrm{CHO}+\mathrm{CH}_{3}-\mathrm{CH}_{2}-\mathrm{CH}_{2}-\mathrm{CH}_{2}-\mathrm{CHO}+\mathrm{H}_{2} \mathrm{O}
\end{aligned}
$$

The created two molecules of aldehyde are further oxidized into a carbonic acid. 


$$
\begin{aligned}
& 2 \mathrm{CH}_{3}-\mathrm{CH}_{2}-\mathrm{CH}_{2}-\mathrm{CHO}+\mathrm{O}_{2} \longrightarrow 2 \mathrm{CH}_{3}-\mathrm{CH}_{2}-\mathrm{CH}_{2}-\mathrm{COOH} \\
& 2 \mathrm{CH}_{3}-\mathrm{CH}_{2}-\mathrm{CH}_{2}-\mathrm{CH}_{2}-\mathrm{CHO}+\mathrm{O}_{2} \longrightarrow 2 \mathrm{CH}_{3}-\mathrm{CH}_{2}-\mathrm{CH}_{2}-\mathrm{CH}_{2}-\mathrm{COOH}
\end{aligned}
$$

When the oxygen molecule joins the other created, which are also oxidized into a carbonic methylene group, both ketone and aldehyde are acid, namely:

$$
\begin{aligned}
& \mathrm{CH}_{3}-\mathrm{CH}_{2}-\mathrm{CH}_{2}-\mathrm{CHOH}-\mathrm{CH}_{2}-\mathrm{CH}_{2}-\mathrm{CH}_{2}-\mathrm{CH}_{2}-\mathrm{CH}_{3}+\mathrm{O}_{2} \longrightarrow \\
& \mathrm{CH}_{3}-\mathrm{CH}_{2}-\mathrm{CH}_{2}-\mathrm{CHOH}-\mathrm{CH}_{2}-\underset{\mid}{\mathrm{CH}}-\mathrm{CH}_{2}-\mathrm{CH}_{2}-\mathrm{CH}_{3} \longrightarrow \\
& \mathrm{OOH} \\
& \mathrm{CH}_{3}-\mathrm{CH}_{2}-\mathrm{CH}_{2}-\mathrm{CHO}+\mathrm{CH}_{3}-\underset{\|}{\mathrm{C}}-\mathrm{CH}_{2}-\mathrm{CH}_{2}-\mathrm{CH}_{3}+\mathrm{H}_{2} \mathrm{O} \longrightarrow \\
& \mathrm{O} \\
& 2 \mathrm{CH}_{3}-\mathrm{CH}_{2}-\mathrm{CH}_{2}-\mathrm{CHO}+\mathrm{O}_{2} \longrightarrow 2 \mathrm{CH}_{3}-\mathrm{CH}_{2}-\mathrm{CH}_{2}-\mathrm{COOH} \\
& \begin{array}{cc}
\mathrm{CH}_{3}-\underset{\mathrm{O}}{\mathrm{C}}-\mathrm{CH}_{2}-\mathrm{CH}_{2}-\mathrm{CH}_{3}+\mathrm{O}_{2} \longrightarrow \mathrm{CH}_{3}-\underset{\mathrm{C}}{\mathrm{C}}-\mathrm{I}-\mathrm{CH}_{2}-\mathrm{CH}_{3} \\
\mathrm{C}
\end{array} \\
& \mathrm{CH}_{3} \mathrm{CHO}+\mathrm{CH}_{3}-\mathrm{CH}_{2}-\mathrm{COOH} \\
& 2 \mathrm{CH}_{3}-\mathrm{CHO}+\mathrm{O}_{2} \longrightarrow 2 \mathrm{CH}_{3}-\mathrm{COOH}
\end{aligned}
$$

Thus, as a result of oxidation from one molecule of aliphatic alcohol, nearly four molecules of carbonic acids are obtained.
In the presence of polyethylenpolyamine with the sorbed ions $\mathrm{Co}^{2+}$, the oxidation of nonanon-4 is as follows:

$$
\begin{gathered}
{[\mathrm{PEPA}] \mathrm{Co}^{2+}+\mathrm{O}_{2} \longrightarrow\left[\mathrm{PEPA} \mathrm{Co}{ }^{2+} \cdot \mathrm{O}_{2}\right]} \\
\mathrm{CH}_{3}-\mathrm{CH}_{2}-\mathrm{CH}_{2}-\underset{\mathrm{C}}{\mathrm{C}}-\mathrm{CH}_{2}-\mathrm{CH}_{2}-\mathrm{CH}_{2}-\mathrm{CH}_{2}-\mathrm{CH}_{3}+\mathrm{O}_{2} \longrightarrow \\
\mathrm{CH}_{3}-\mathrm{CH}_{2}-\mathrm{CH}_{2}-\underset{\|}{\mathrm{C}}-\mathrm{CH}-\mathrm{CH}_{2}-\mathrm{CH}_{2}-\mathrm{CH}_{2}-\mathrm{CH}_{3} \longrightarrow \\
\mathrm{O} \mathrm{OOH} \\
\mathrm{CH}_{3}-\mathrm{CH}_{2}-\mathrm{CH}_{2}-\mathrm{CHO}+\mathrm{CH}_{3}-\mathrm{CH}_{2}-\mathrm{CH}_{2}-\mathrm{CH}_{2}-\mathrm{COOH} \\
2 \mathrm{CH}_{3}-\mathrm{CH}_{2}-\mathrm{CH}_{2}-\mathrm{CHO}+\mathrm{O}_{2} \longrightarrow 2 \mathrm{CH}_{3}-\mathrm{CH}_{2}-\mathrm{CH}_{2}-\mathrm{COOH}
\end{gathered}
$$


Thus, as a result of oxidation from one molecule of naonanon-4, one molecule of carbonic acid and one molecule of aldehyde are obtained which are also oxidized into a carbonic acid.
In case of the oxygen molecule joining another methylene group, the reaction can be presented as follows:

$$
\begin{aligned}
& \mathrm{CH}_{3}-\mathrm{CH}_{2}-\mathrm{CH}_{2}-\underset{\|}{\mathrm{C}}-\mathrm{CH}_{2}-\mathrm{CH}_{2}-\mathrm{CH}_{2}-\mathrm{CH}_{2}-\mathrm{CH}_{3}+\mathrm{O}_{2} \\
& \mathrm{O} \\
& \mathrm{CH}_{3}-\mathrm{CH}_{2}-\mathrm{CH}_{2}-\underset{\|}{\mathrm{C}}-\mathrm{CH}_{2}-\underset{\mid}{\mathrm{CH}}-\mathrm{CH}_{2}-\mathrm{CH}_{2}-\mathrm{CH}_{3} \\
& \mathrm{O} \quad \mathrm{OOH} \\
& \mathrm{CH}_{3}-\mathrm{CH}_{2}-\mathrm{CH}_{2}-\underset{\mathrm{C}}{\mathrm{C}}-\mathrm{CH}_{3}+\mathrm{CH}_{3}-\mathrm{CH}_{2}-\mathrm{CH}_{2}-\mathrm{COOH} \\
& \mathrm{O} \\
& \mathrm{CH}_{3}-\mathrm{CH}_{2}-\mathrm{CH}_{2}-\underset{\|}{\mathrm{C}}-\mathrm{CH}_{3}+\mathrm{O}_{2} \longrightarrow \mathrm{CH}_{3}-\mathrm{CH}_{2}-\underset{\text { C }}{\mathrm{CH}}-\underset{\|}{\mathrm{C}}-\mathrm{CH}_{3} \longrightarrow \\
& \mathrm{O} \\
& \mathrm{OOH} \mathrm{O} \\
& \mathrm{CH}_{3}-\mathrm{CH}_{2}-\mathrm{COOH}+\mathrm{CH}_{3}-\mathrm{CHO} \\
& 2 \mathrm{CH}_{3}-\mathrm{CHO}+\mathrm{O}_{2} \longrightarrow 2 \mathrm{CH}_{3}-\mathrm{COOH}
\end{aligned}
$$

If the presented schemes of the oxidation of aliphatic alcohol and ketone are fair, then the observed high yield of carbonic acids becomes a logical consequence of existing reactions.

It should also be noted that in oxidation reactions in the presence of complex [PEPA $] \mathrm{Co}^{2+}$ decarbooxidation of carbonic acids is practically absent. Obtained results are presented in Table 1.

Table 1. The quantity of evolved carbon dioxide in different systems.

\begin{tabular}{|c|c|c|}
\hline Compound & Metal ions & Quantity of $\mathrm{CO}_{2}, \mathrm{~mol}$ \\
\hline Nonanol-4 & $\mathrm{Co}^{2+}$ & 0.2 \\
\hline Nonanon-4 & $\mathrm{Co}^{2+}$ & 0 \\
\hline Nonanon-4 & $\mathrm{Cu}^{2+}$ & 2.15 \\
\hline Nonanon-4 & $\mathrm{Ni}^{2+}$ & 2.2 \\
\hline Nonanon-4 & Therm & 0 \\
\hline
\end{tabular}

On the basis of the obtained experimental material we can conclude that the ions $\mathrm{Co}^{2+}$ sorbed on polymer matrix PEPA initiate the process of oxidation of aliphatic alcohol and ketone and selectively lead the reaction towards the preferential formation of carbonic acids. 


\section{References}

1. Mukhambetova G.E., Tashmukhambetova Zh.Kh., Shokorova L.A.. Liquid-phase oxidation of hydrocarbons on metal complex catalysts, Almaty, Kazakhstan, Abstracts dokl. Int. conf. Stud. and young scientists "World of Science", 2011, p.100.

2. Lunin A.V., Danov S.M., Fedosov A.E., Fedosova M.E. Kinetics of liquid-phase oxidation of n-alkanes with hydrogen peroxide on a heterogeneous catalyst DP-1. Fine Chemical Technologies. 2014, vol. 1, no. 1, pp. 59-63.

3. Vasilieva E.A., Mukhamedzyanov,R.R. Sitmuratov T.S., Akhmedyanova R.A., Petukhov A.A., Beskrovny D.V., Miloslavsky D.G. Homogeneous catalytic oxidation of ethylbenzene with atmospheric oxygen in the presence of organic cobalt (II) salts. Bulletin of Kazan Technological University, 2017, vol. 20, no. 15, pp. 57.

4. Iwahama T., Yosino Y., Keitoku T., Sakaguchi S., Ishii Y. Efficient Oxidation of alcohols to carbonyl compounds with molecular oxyden catalyzed by $\mathrm{N}$ hydroxyphthalimide combined with a Co species. J. of Organic Chemistry, 2000, vol. 65, no 20, pp. 6502-6507.

5. Denisov E.T., Miscavige N.I., Agabekov V.E.. The mechanism of liquid-phase oxidation of oxygen-containing compounds, Belarus Minsk: Science and technology Publ. 1975, p. 334.

6. Coleman K.S., Coppe M., Thomas C., Osborn J.A. Catalytic oxidation of alcohols into aldehydes and ketones by an osmiumcopper bifunctional system using molecular oxygen. Tetrahedron Letters, 1999, vol. 40, no. 19 , pp. 3723-3729.

7. Ranveer A.C., Ranade S.V., Mistry C. Selective oxidation of alcohols to aldehydes by using hydrogen peroxide as an oxidant: a review. Intern. J. of Advance Research in Science and Engineering, 2015, vol. 4, special Issue 01, pp. 277-288.

8. Efendiev A.A., Orujev J.J., Ragimova
A.M., Suleymanova R.G., Huseinova S.H., Zeinalova M.B., Shakhtakhtinsky T.N. Liquid-phase oxidation of hydrocarbons in a presense of metal-polymer complex catalysts with specially designed structure centers, Abstracts of VI International Simposium «Relations Between Homogeneous and Heterogenous Catalysis». Pisa. Italy. 1989, p. 97-98.

9. Suleymanova R.G., Zeynalov N.A., Badalova O.T., Kulubekova L.N., Sharifzade N.F., Kuliyeva A.R. Liquidphaze oxidation of aliphatic hydrocarbons in a presence of metalpolymer complexes. Azerb. Chem. Journal, 2016, no. 4, pp. 8084.

10. Emanuel N.M., Denisov E. T., Maisus Z. K. Chain reactions of hydrocarbon oxidation in the liquid phase. Moscow: Nauka Publ. 1965, p. 374.

11. Aqafonov E.D., Arlovskaya N.F. Mathematical simulation of hexadecane oxidation processes. Tomsk State University J. of Control and Computer Science. 2013, no. 4 (25), pp. 5-15.

12. Suleymanova R.H., Zeynalov N.A., Badalova O.T., Qulubayova L.N., Guliyeva A.R., Kerimova N.A. Research into kinetic regularities of catalytic liquid-phase oxidation of $n$-hexadecane in the presence of metalcomplexes calalysts. Chemical Problems, 2019, no. 3(17), pp. 417-422.

13. Suleymanova R.G., Zeynalov N.A., Badalova O.T., Kulubekova L.N., Kuliyeva A.R., Isazade A.F. Studying the reaction of cyclohexanone oxidation in the presence of polymeric complexes of polyethylenimine arranged to copper and nickel. Azerb. Chem. Journal. 2017, no. 4, pp. 55-59.

14. Suleymanova R.G., Zeynalov N.A., Badalova O.T., Kulubekova L.N., Kuliyeva A.R., Isazade A.F. Research into reaction of liquid-phase oxidation of cyclohexanone on metalpolymer complexes. Chemical Problems, 2017, no. 4, pp. 442-447. 


\title{
METAL POLIMER KOMPLEKSLORIN ISTIRAKI ILOOKSIGEN TORKIBLI ALIFATIK KARBOHIDROGENLORIN KATALITIK OKSIDLOSMMOSI
}

\author{
R.H. Süleymanova, N.A. Zeynalov, O.T. Badolova, L.N. Qulubəyova, \\ A.R. Quliyeva, Ü.Ә. Mommədova \\ AMEA akademik M.Nağıyev adına Kataliz və Qeyri-üzvi Kimya İnstitutu \\ AZ 1143 Bakı şəh., H. Cavid pr.113, e-mail:suleyman.rena@gmail.com
}

\begin{abstract}
Dayişkan valentli metal ionlarl $\left(\mathrm{Co}^{2+}, \mathrm{Cu}^{2+}, \mathrm{Ni}^{2+}\right)$ sorbsiya olunmuş polietilenpoliamin komplekslarinin iştirakı ila oksigen tarkibli alifatik karbohidrogenlarin, o cümladən nonanol-4 va nonanon-4-ün maye fazada oksidloşmə reaksiyası öyranilmişdir. Göstərilmişdir ki, öyrənilmiş sistemdə $\mathrm{Cu}^{2+}$ və $\mathrm{Ni}^{2+}$ ionlarının iştirakı ilo nonanol-4 vo nonanon-4-ün oksidloşməsi zamanı katalizatorların aktivliyi azalır, $\mathrm{Co}^{2+}$ ionlarının iştirakında iso artır, belo ki, kobalt ionlarının iştirakı ila turşuların dekarboksilloşməsi praktiki olaraq baş vermir, bu da osasən karbon turşularının yaranmasına gatirib çıxarır. Müəyyən edilmişdir ki, oksidlaşmə reaksiyasının xarakteri polimer matrisasına barkidilmiş metal ionlarının xassalorindan ahəmiyyatli daracado asılıdır.
\end{abstract}

Açar sözlor: maye faza, oksidlaşmə, metal polimer komplekslar, nonanol-4, nonanon-4, karbon turşularl

\section{КАТАЛИТИЧЕСКОЕ ОКИСЛЕНИЕ КИСЛОРОДСОДЕРЖАЩИХ АЛИФАТИЧЕСКИХ УГЛЕВОДОРОДОВ В ПРИСУТСТВИИ МЕТАЛЛОПОЛИМЕРНЫХ КОМПЛЕКСОВ}

\author{
Р.Г. Сулейманова, Н.А. Зейналов, О.Т. Бадалова, Л.Н. Кулибекова, \\ А.Р. Кулиева, У.А. Мамедова \\ Институт Катализа и Неорганической химии имени академика М.Нагиева \\ Начиональной АН Азербайджана \\ AZ 1143 Баку, пр. Г. Джавида,113, e-mail: suleyman.rena@ gmail.com
}

Изучены реакиии жидкофазного окисления алифатических кислородсодержаших углеводородов, в частности нонанола-4 и нонанона-4 в присутствии комплексов полиэтиленполиамина с ионами металлов переменной валентности $\left(\mathrm{Co}^{2+}, \mathrm{Cu}^{2+}, \mathrm{Ni}^{2+}\right)$. Показано, что при окислении нонанола-4 и нонанона-4 в присутствии ионов $\mathrm{Cu}^{2+}, \mathrm{Ni}^{2+}{ }_{6}$ изученной системе активность катализаторов низкая, а в случае ионов $\mathrm{Co}^{2+}$ она увеличивается, т.к. практически отсутствует декарбоксилирование кислот, что приводит в основном к образованию карбоновых кислот. Установлено, что характер реакции окисления существенно зависит от свойств металлов, закрепленных на полимерной матрице.

Ключевые слова: жидкая фаза, окисление, металлополимерные комплексы, нонанол-4, нонанон-4, карбоновые кислоты. 